\title{
The use of nursery rhymes to teach writing for the eighth grade students of SMPN 2 Geger
}

\author{
Maria Agustina Astuti Siba Lian', Nuri Ati Ningsih ${ }^{2}$ \\ ${ }^{1,2}$ Department of English Teaching, Faculty of Teacher Training and Education \\ Universitas PGRI Madiun
}

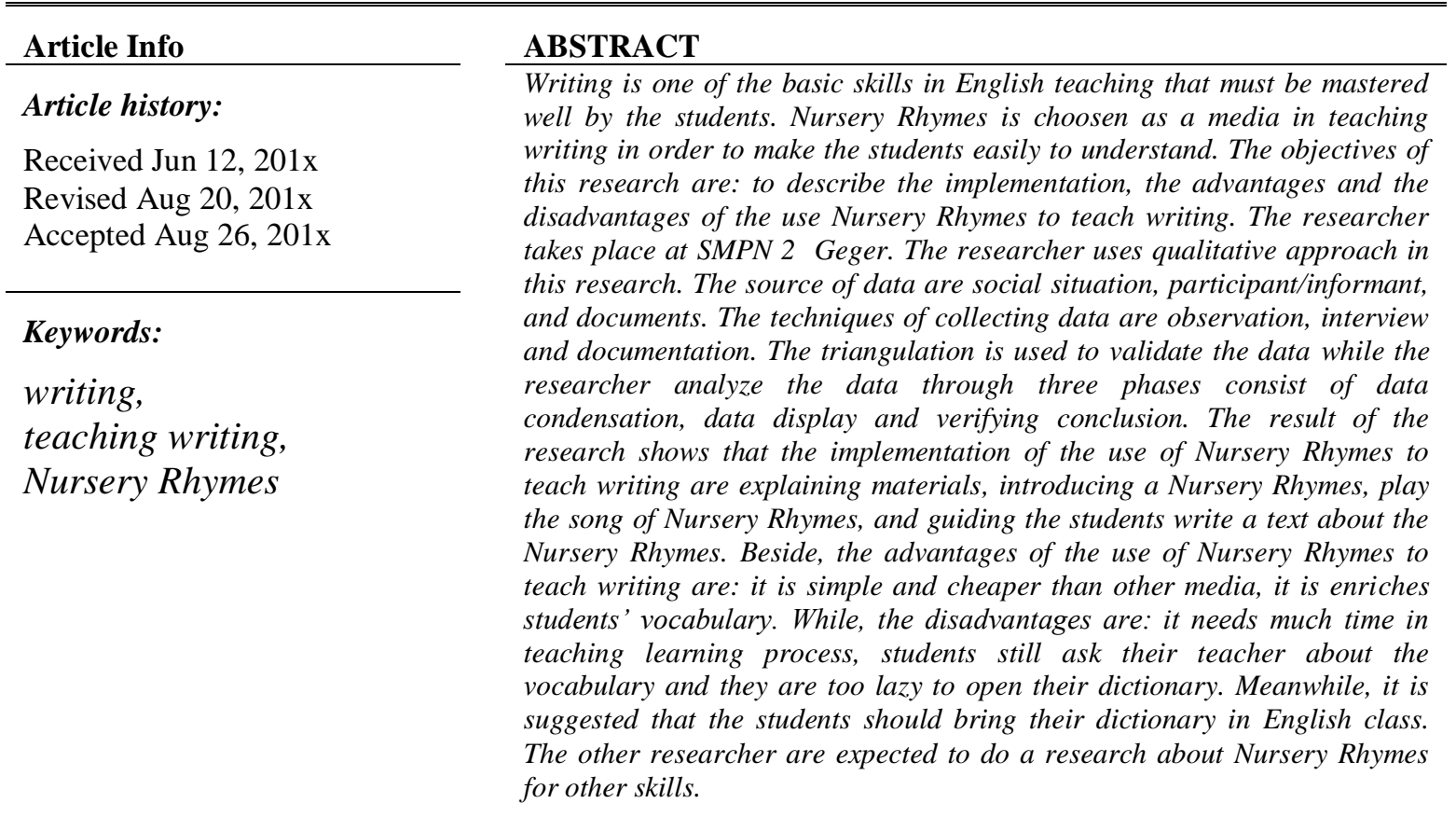

Copyright $@ 2019$ Department of English Teaching. All rights reserved.

Corresponding Author:

Maria Agustina Astuti Siba Lian, Nuri Ati Ningsih

Department of English Teaching, Faculty of Teacher Training and Education

Universitas PGRI Madiun

Jalan Setiabudi No.85 Madiun

Email: marialian108@gmail.com

\section{INTRODUCTION}

Language is the most important of human life as a media to communicate with other people. The purpose of language is to communicate, wether by talking or writing. English is an international language as communication media for people in the world. English is important for everyone especially students. Mastering English makes students have wider knowledge because they can find more source of knowledge by literature in English. Crystal (2003:110) said that based on investigation, one of the most important reason why English, in many countries, is choosen as an official language or their chief foreign language at school is always educational. That is the point that makes English is an important language to make the student more competent.

Writing is productive categorized in learning English. Hibbard and Wagner (2013:56) define writing as a process of learning through constructing complete though on the paper. Writing is one of skills in 
learning English which is taught in the school. The process of writing greatly influences to the final product of writing. However, there are several problems happened. The problems come from both of students and the English teacher.In teaching writing, the teacher also still has some weaknesses. In the class, the teacher often orders the students to make a piece of writing project. In this case, the teacher just command the students to make a writing project without explaining the steps clearly. It looks that the teacher does not conduct the students' written work and still neglects the process. The teacher never uses an attractive media or innovative technique in order to make the students are interested in writing class. It makes the teaching learning process feel bored and the process of transfering knowledge does not run well.

The teacher should use a media to make easier and to be more fun in the teaching learning activities for the students to learn. Smaldino (2005: 9) states that media refers to anything that carries information between a source and receiver. It means that media can help the teacher to transfer material or to make easily the students get the concept of the material. The teacher should prepare appropriate media to teach writing in learning process. There are many kinds of media can be used in teaching learning proces. Such as visual, audio, audio visual, multimedia, and realia. Audio is a media which simply be heard. The example are audio tapes, mp3, radio. Nursery Rhymes are kinds of poem or song that can be heard by using audio. Therefore, It can be classified that Nursery Rhymes as a media in teaching learning process.

The researcher is interested to use Nursery Rhymes to teach writing because this media would make the children easier in writing skill. As the researcher knows that Nursery Rhymes as a simple poem or song is easy to remember, so it will probably stuck in children's mind which is easier for the teacher to teach English writing by using Nursery Rhymes. In this research, the researcher limits the investigation in teaching learning process. The activity of teaching learning process in SMPN 2 Geger for the eighth grade. The researcher focuses in teaching English writing by using Nursery Rhymes. The researcher hopes that the media can make the students interested and enjoyed in teaching and learning English.

\section{RESEARCH METHOD}

In this research, the researcher uses qualitative research that focus in the condition of the place which is purpose to get uderstanding about a phenimenon in the place by describing, analyzing and interpreting the condition. According to Denzin and Lincoln (2005) qualitative researcher locate themselves betweeen post and positivism and post structuralism. This means that qualitative research study things in their naturalistic settings, attempting to make sense of or interpret phenomena in terms of meanings people bring them.

Research design is very important in doing research. Yin (2002: 75) says that reseach design are logical blueprints. The designs serve as "logical" plans, not the "logistic" plans often referenced by others. The logistics plans are still needed but cover the management of your research, such as scheduling and coordinating of the work. It means that research design describes the elements of planning the research as effective as possible.

In this research, the researcher uses qualitative research which focuses on natural condition in a place. According to Creswell (2007: 36) qualitative research is an activity that locates the observer in the world. It consist of a set of interpretive and material practice that make the world visible. These practices transform the world. They turn the world into a series of representation, including fieldnotes, interviews, and photograph. The source of data can help the researcher to answer the research question. In this research, source of data includes social situation, informants or participants, and document. They are social situation, participants/informants, and documents.

Data Reduction is technique of analyzing data in qualitative research that data reduction refers to the process of selecting, focusing, simplifying, abstracting and transforming the data that appear in written filledup notes or transcription. The researcher compress the data from those activities in the classroom to know the implementation of Nursery Rhymes to teach writing and reduce the data which got from interview between English teacher and some students to know the advantages and disadvantages in the implementation of Nursery Rhymes.

After the researcher finishes the reduction, the next is data display or displaying the data. According to Berg (2001: 35-36) The notion of data display is intended to convey the idea that data are presented as an organized, compressed assemly of information that permits conclusion to be analytically drawn. This process is consist of organizing and compressing infromation to make a conclusion. It can be concluded that data display will help the reseacher to represent the ways of organizing, summarizing, simplifying, or 
transforming data. In this research, the researcher displays some data in the form of briefly description. The data in order to give clear description about the implementation of this media and result of the research. The data will be displayed include the data from observation, interview, and documentation the use of Nursery Rhymes to teach writing for the Eighth grade students of SMPN 2 Geger in the schooling year 2019/2020.

Verification is the process to prove that something is correct. In this research, the reseacher needs to make a conclusion about the use of Nursery Rhymes as a media to teach writing and verifiying the data collected. In this research, the researcher used the triangulation to get validity the data. Data triangulation used to make sure the researchers' understanding of the issues and maximize their confidence in the finding of qualitative research. According to Bogdan and Biklen (2007: 115), Triangulation was first borrowed in the social sciences to convey the idea that to establish a fact you need more than one source of information. It means that, triangulation data are shown by using different sources of information to escalate the validity of data. In triangulation, there are three ways to verifying the data. According to Bergh (2001: 6) triangulation includes multiple data-collection procedures, multiple theoritical prespectives, and multiple analysis technique. In this research, the researcher uses multiple data-collection procedures triangulation to get the validity of data. The researcher needs to find support data in more than one data source. The researcher uses different method of data collection technique, they are observation, interviewing and documenting. The researcher gets the obsevation in SMPN 2 Geger, interviewing with the teacher and students, then took the photos, syllabus, lesson plans, students' attendance, student's worksheet and students' score as a document.

After the researcher has done the planning, the researcher should apply the research in the real condition. The stages of aaplication are divided into two points. First, collecting the data are observing the English teaching and learning process in English subject, making an interview section with English teacher in the class, taking the students' achievement or report in learning process, collecting docement from school, analyzing the data. Second, classifying the data are processing the data and inishing the data.

After collecting the data, the researcher arranges the result of the study. All data that will be annalyze are reported and written through a thesis entitled "The use of Nursery Rhymes to teach writing for the eighth grade students of SMPN 2 Geger in the schooling year 2019/2020.

Based on explanation above, it can be concluded that procedures of research iclude planning, aplication, and reporting. Planning is activities that done before doing the research. Application is the activities in doing research include collecting the data and analyzing the data. Reporting is the researcher arranges the result of study in form of theis writing.

\section{RESULTS AND DISCUSSION}

Nursery Rhymes can make exploration of vaules. Santovac (2012) states when choosing rhymes to use in the classroom, teachers should pay attention to how well they lend themselves to the exploration of different values through different content. Based on the result of data collected from observation, interview and documentation, the researcher discusses about the activities of the teacher in the students in the teaching writing by using Nursery Rhymes for the eighth grade students of SMPN 2 Geger. There are two activities consist of preparation and teaching learning process. It will be described as follows:

\section{a. Preparation steps}

Preparation is an activity that should done by the teacher before doing learning process in the class. The researcher prepares the instruments to teach like syllabus, lesson plan, and student worksheet before teaching and learning process.

b. Teaching and learning process

In this research, there are some steps have done by the teacher in the teaching learning process. They are pre-activities, whilst-activities, post-activities. The steps explained as follows:

1) Pre-activities

Pre-activities are the opening activity in the teaching learning process. In pre-activities there are some activities consist of the teacher's greeting, praying, checking the students' attendance list, giving apreception and explained the goals of the study. In this step, the teacher does some activities. First, the teacher greets the students. Then the students give the response. Second, the teacher asks the readiness of the students to study English. After that the teacher checks the student attendances. Third, the teacher explains about the purpose of the material to the students. Then, the teacher gives brainstorming by asking a question relates with the material.

2) Whilst-activities

In the whilst-activities, the teacher does the main activities during the teaching and learning process by using Nursery Rhymes. First, the teacher explains the material about the message of song, then the teacher checks the students understanding and the students answer the question from the teacher. he teacher plays an audio and the students listen the song. Then, the teacher asks the students to write 
down the word that they have heard on the paper. They may checked the meaning on the dictionary. After that the teacher plays the audio again and asked the students to complete the blank words on the worksheet. Then the teacher plays the audio again and asks the students to sing the song together based on the complete lyrics. Next, the teacher asks the students to make a group that consists of 4-5 students. Then, the teacher asks each group to discuss with their member and make a simple paragraph about the song. After all the student finished the writing based on Nursery Rhymes that given by the teacher, they have to collect their worksheet. The student read their work in front of the class. Then, the teacher gives some evaluation the teaching and learning process. The teacher gives time 10 minutes to the student to finish this evaluation. After that, the teacher asks the difficulty about the material to the students. Then, the teacher gives the review about the material by giving a question. Then the students give the answer based on their understanding.

3) Post-activities

In the post activities, the teacher does some activities after the discussion and explains material was over. The teacher ends the teaching and learning process by doing some activities. The first activity, teacher makes the summarized about the material today. The second activity is greeting.

1. The advantages and disadvantages of using Nursery Rhymes to teach writing for the eighth grade stduents of SMPN 2 Geger.

In this part, the researcher will discuss about the advantages and disadvantages the use of Nursery Rhymes to teach writing for the eighth grade students of SMPN 2 Geger. There were some advantages and disadvantages of the implementing Nursery Rhymes to teach writing. According to Sayakhan and Bradley (2014) Nursery Rhymes can be one part of teaching English as a Foreign Language (EFL) that have a long tradition of political meanings, which can make them more interesting for learners. The advantages of the implementation Nursery Rhymes to teach writing for the eighth-grade students of SMPN 2 Geger: It was a simple than other media, It was enriched vocabulary knowledge for students, It made students more interesting in a writing process especially in the activity of writing, It made the classroom and students' condition more active and live.

Besides, the disadvantages of the implementation Nursery Rhymes: It needs much time to play the audio because the students did not focus on the lyrics from the song, students still asked their teacher about the vocabulary and they were too lazy to try opens their dictionary, some of the students still confused about the simple present tense so it needed a long time for them to wrote a sentences..

\section{CONCLUSION}

The use of Nursery Rhymes to teach writing for the eighth grade students of SMPN 2 Geger is done into three stages which consist of pre-activities, whilst-activities, and post activities. Pre-activities consist of the teacher entering classroom then greeting to the students, checking the students' attendance and also the classroom condition. Whilst activity consist of explaining the materials about the message of song, introducing Nursery Rhymes, explaining the steps of implementation Nursery Rhymes and guiding the students to make simple paragraph about the message of the song is worked by their group. Then they concluded what they discuss in the group. One of the group come forward to read their text. The students back on their own sit and submit their work to the teacher. In post-activities, the teacher gives comment and praises to the students, reviews and checks the students' understanding about the material that have been discussed. The teacher also asked the students difficulties during the learning process and closes the teaching learning process. There are some advantages and disadvantages of the implementation of Nursery Rhymes to teach writing for the eighth grade students based on the observation, interviews and documentation. There are some advantages, the first is Nursery Rhymes was a simple than other media. Second, It was enriched vocabulary knowledge for students. Third, It made students more interesting in a writing process especially in the activity of writing. Last, It made the classroom and students condition more active and live.

The suggestion belongs to the teacher, the students, the educational institution and the other researcher as follows: The teacher has to be creative in teaching to make the students study enthusiastically, the teacher is expected to use Nursery Rhymes for teaching writing as one of many alternatives media that can be used to improve students' ability in writing skill. The students are expected to have a lot of practiced in writing. Therefore, they can increase the vocabulary, become fluent to make sentences, and be more creative to write a text. The researcher hopes that the educational institution gives facilitate in supporting the creative ideas and other education equipment to develop the knowledge, experience and ability for the

English Teaching Journal, Vol. 7, No. 1, June 2019: $33-37$ 
teacher and the students in learning activity. The researcher hopes this research can give information and reference for the other researcher. The researcher suggested that the other researcher can conduct another research in English teaching, especially for teaching writing.

\section{REFERENCES}

Berg, B.L. (2001). Qualitative Research Method for The Social Science ( ${ }^{\text {th }}$ ed). Boston: Allyn \& Bacon.

Bogdan, R,C., \& Biklen, S.K. (2007). Qualitative Research for Education An Introduction to Theories and Methods ( $5^{\text {th }}$ ed). Boston: Pearson Education.

Creswell, J.W. (2007). Qualitative Inquiry \& Research Design Choosing Among Five Approaches $\left(2^{\text {nd }}\right)$ ed. California: Sage Publication

Crystal (2003). English as a Global Language $2^{\text {nd }}$ ed. New York: Cambridge University

Denzin, N.K., \& Lincoln, Y.S. (2005). Introduction: The discipline and practice qualitative research. In N.K. Denzin \& Y.S. Lincoln (Eds.), The sage handbook of qualitative research $\left(2^{\text {nd }} e d\right.$.). Thousand Oaks, CA: Sage.

Hibbard, M., \& Wagner, E. (2013). Assessing and Teaching Reading Composition and Writing. New York: Routledge.

Najat Ismael Sayakhan, Darcy H. Bradley. Nursery Rhymes as a Vehicle for TeachingEnglish as a Foreign Language. International Journal. of Literature and Arts. Vol. 2, No. 3, 2014, pp. 84-87. doi: 10.11648/j.ijla.20140203.15

Yin, R. (2011). Qualitative Research from Start to Finish. Ney York: The Guildfold Press. 